\title{
Android-Based "Idea Bank" Application as Media E-Learning in Courses Change Management
}

\author{
Elfia Nora $^{\text {a, *, Afwan Hariri Agus Prohimi }}{ }^{\text {b }}$, Lohana Juariyah c \\ ${ }^{a, b, c}$ Department of Management, State University of Malang \\ Semarang Street, Number 5, Malang, East Java, Indonesia \\ *Corresponding author's e-mail: elfia.nora.fe@um.ac.id
}

\begin{abstract}
During this time for change management lectures, it is still often conveyed by the method of lectures and group discussions on cases of change in the industry and its management. Idea Bank application will be expected to be a reference for students to pour ideas of change, try to design changes, keep documentation of the implementation of changes they make, so that the idea of changes and innovations made by students in this application later may also be useful for the State University of Malang, because during this time the tasks carried out by students are more often stored in hard copy, or soft copy personally by lecturers who foster the subject.

The purpose of developing e-learning media in change management courses in the form of android-based "idea bank" application is to create more innovative electronic learning media and provide more interactive learning media to students in accordance with the millennial era they live in. Learning tools developed in the form of Electronic Learning Media Applications stored on HP Android can be installed through the Play Store labeled "Idea Bank", where in it there will be several features namely problem portrait feature, Idea Change feature, Idea Design feature, theory change feature, Idea Succes feature, and some electronic program tools, including save menu, table data filling menu, upload documentation and others.

The development method is Borg \& Gall development model (1996) using water fall flow at the development stage. Stages of development ranging from needs analysis, product planning, product development, trial / implementation (validation), revision and report creation. Product results in the form of Idea Bank Application in the form of problem portrait feature, Idea Change feature, Idea Designfeature, theory change feature Idea Succes Feature. stored on HP Android and also application usage tutorial.
\end{abstract}

Keywords: Application; Idea Bank; E-learning. 


\section{Introduction}

In this Era of Industrial Revolution 4.0, all activities related to the teaching and learning process must also be adjusted to the demands of Industrial Revolution 4.0, where students at universities now belong to the category called Millennial students prefer and rely on gadgets and laptops in finding information and doing all the tasks given by lecturers. So that in the learning process lecturers must be more interactive and innovative and want to change their teaching direction, by utilizing their Android gadgets as an interesting learning media so that students have the motivation to listen and implement what has been learned in lectures. Learning media can be used to create real learning conditions, so as to adapt to each individual's diverse learning style. For example, lecturers convey a message about the example of a case in the organization, when lecturers only explain by lecturing only then students will only imagine in the abstract, and sometimes forget, but when lecturers use Powert Point as a tool, even using video related learning cases, or students are asked to directly practice using the software that has been provided as a learning medium, this will be easier for students to get a real picture of a learning so that they can understand correctly and even contribute to learning.

Asyhar (2012: 8) said learning media can be understood as everything that can convey or channel messages from the source in a planned manner, so that there is a conducive learning environment where the recipient can conduct the learning process efficiently and effectively. Learning media today is very varied, and electronic learning media or E-Learning is very supportive of learning today. Gerlach and Ely (in Arsyad, 2011: 3) broadly explain that learning media are human beings, materials, or events that build conditions that make students able to acquire knowledge, skills or attitudes. Sudjana (2002: 7) which states that learning media is a teaching tool, namely to support the use of teaching methods used by teachers. So, it can be concluded that the learning media is a tool for teachers or lecturers in delivering learning materials to students consisting of books, tape recorders, tapes, video cameras, video recorders, movies, slides (picture frames), photos, pictures, televisions and computers. The computer learning process acts as a manager, known as computermanaged instruction (CMI). On the other hand, the role of computers is utilized to present information on the content of lesson materials, exercises, or both, the role of computers as additional helpers in learning. This mode is known as computer-assisted instruction (CAI), which supports learning and training but is not the main presentation of subject matter. Computer-assisted instruction (CAI) is expected to create effective learning (Azhar, 2007: 96). Computer-based learning is able to encourage and enable interaction and mutual help between students who are still laymen and those who have mastered it thus students can play an active role in every learning 
activity. At the Faculty of Economics, Department of Management, Change Management courses are courses that must be taken or taken by all students in the department, especially S1 Management. This course learns about problem identification so that the need for an organizational change, formulating changes (change ideas), change strategies, change design, implementation of change, resistance and acceptance of change, leadership change, and cultural change of an organization this change management lecture material is very related to innovation, or change ideas, and how to manage the implementation of changes where the theory is only as a reference for students to know the state of the organization or company in an abstract, therefore need a more interactive learning media, where later they also pour their ideas into an application that also contains instructions, and theories about change management. During this time for change management lectures, it is still often conveyed by the method of lectures and group discussions on cases of change in the industry and its management. Idea Bank application will be expected to be a reference for students to pour ideas of change, try to design changes, save documentation of the implementation of changes they make, so that the idea of changes and innovations made by students in this application later may also be useful for the State University of Malang, because during this time the tasks carried out by students are more often stored in hard copy, or soft copy personally by lecturers who foster these courses. The purpose of this development research is to develop an application as an android-based E-Learning media to support an interactive and innovative learning process in the Change Management Course. This application is called "Idea Bank" because, students can pour ideas of changes to the features in this application.

\section{Method}

The stages of research on this development are as follows:1) Stages of analysis of development needs: At this stage, what is done is looking for theories or references related to interactive elearningcmedia and observing and interviewing students who have already studied change management courses about deficiencies in the learning process related to learning media and interviewing lecturers who have built change management courses related to the e-learning media used, 2) The stage of development product planning: At this stage what is done is formulating product development objectives, namely to create a more interactive e-learning media change management course in the form of an application in Android called Idea Bank, which can later be installed by students on the Play Store on Android tailored to the needs of today's students, 3) Product development stage: At this stage, what is done is to create e-learning media in the form of problem portrait features, Idea Change features, Idea Design features, theory change features, Idea Success Features, 4) Product trial stages: At this stage what is done is to apply e-learning media in 
the classroom for participants of change management courses by working with lecturers in management courses, then ask the expert validator to assess the validity of the e-learning media development product, 5) Product Revision Stage: at this stage what is done is to correct the shortcomings of the product after being tested in the change management courses class, 6) The stage of report making: At this stage what is done is to make the final report of the results of e-learning media product development, along with presenting the form of the product in the form of an application "Idea Bank" that can be installed on the play store in HP Android.

\section{Results and Discussion}

a. Results of Media E Learning Application Product Creation "Idea Bank"

The development of "Idea Bank" application has been designed before, producing products with display menus in the form of Problem portrait, Idea change, Idea Design, Theory change and Idea success, this product can later be used by students who take change management courses as Emodules, for the application of lecture materials in practice. It contains a table of change ideas, descriptions, analysis and images of the application of ideas submitted.

This application will be able to store, student ideas related to the implementation of a change, can be used by students of any major at the State University of Malang who get a course of Change Management, by installing on google play store, only later to enter the menu, this application is indeed locked with a password, so it can only be used when contacting the application maker first, but temporarily still waiting for approval from the google play store, so that the application is directly shared with students by the development team in the change management class, through Android, students can directly install, and register with the instructions for use shared by the development team. The views the application are as follows:

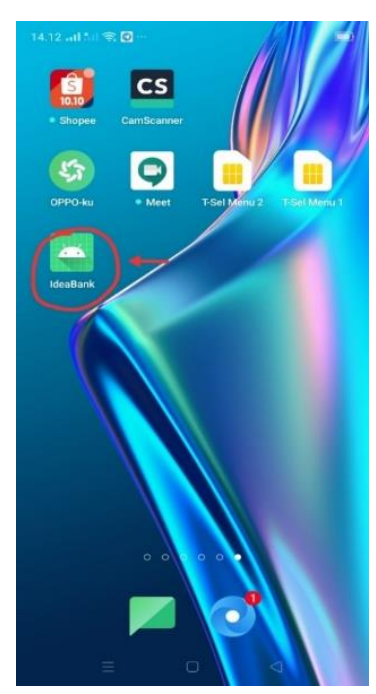

Figure 1. Icon on Android screen 


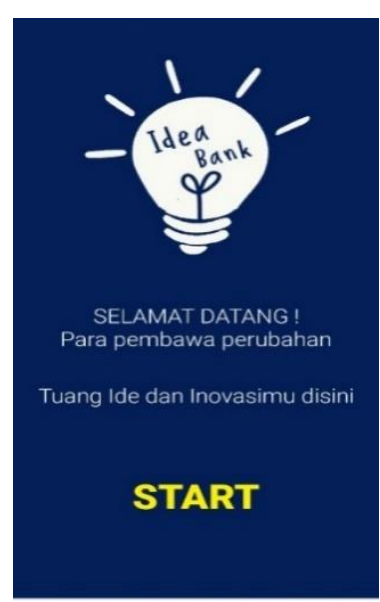

Figure 2. Application Start View

Application usage can be started by clicking "START", to enter the next stage, then will appear the display as below, where the user must fill in the Student Master Number and password, so that it can be sure who can use is the student, then click Register, after register, go again to START to Login.

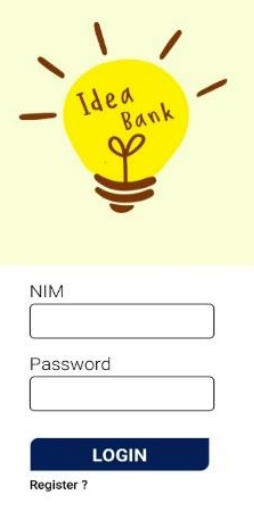

Figure 3. Idea Bank App Login Menu 


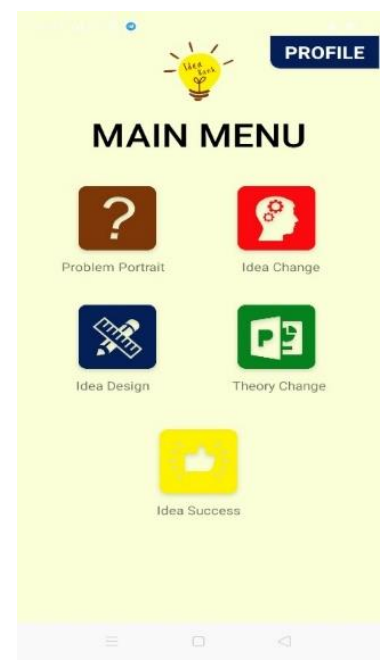

Figure 4. IdeaBank Application Menu

After the user clicks START, it will appear "Main Menu" display, which consists of Problem Portrait with Question Mark Image Icon, Idea Change with Head Image Icon, Idea Design with Icon image ruler and pen, Theory change with Icon book image, and Idea Success with Thumb image Icon, as shown below.

Problem portrait menu can be clicked, to start the work of photographing a problem or identify the problem you want to change, and the following image will appear:

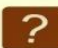

Problem Portrait

Kategori
Problem :

Pertanian

O Pariwisata

UKM

Lainnya
(Sebutkan

industri kreatif

SELANJUTNYA

Figure 5. Problem Portrait Category Selection Menu 


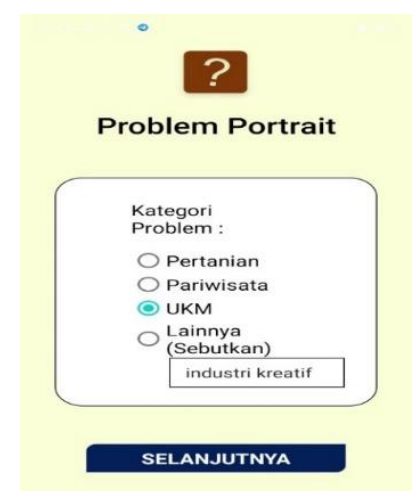

Figure 6. Problem Portrait Options Menu

Then, there are several categories of problems that can be selected according to what the problem wants to be photographed, after clicking on the problem category to be identified, followed by clicking "Next. A worksheet table will appear, with questions to be filled in about identifying what issues to change, after the table is filled, then it can go to the next stage, as shown below. The second problem portrait menu worksheet inserts an image of the condition that will be changed and after it is filled all it can be clicked save menu, so that the work can be saved.

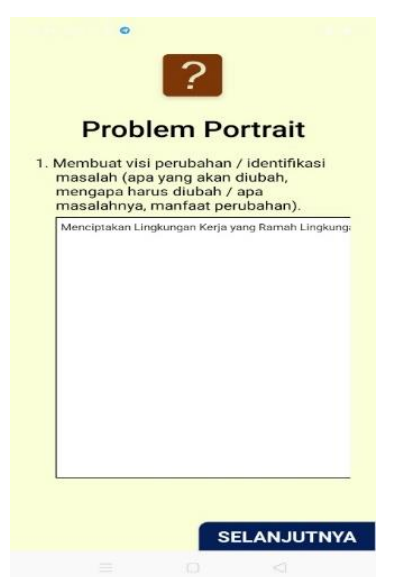

Figure 7. Problem Portrait menu worksheet 1 


\section{?}

Problem Portrait

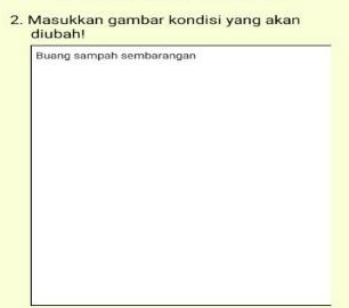

SAVE

Figure 8. Problem Portrait Worksheet Menu 2

Idea change menu contains about what ideas to apply, here users can pour their ideas, in any form. The next change idea contains a worksheet table on Readiness analysis to face resistance and rejection of changes from the change ideas on the previous worksheet, and then the work of Idea Change can be saved.

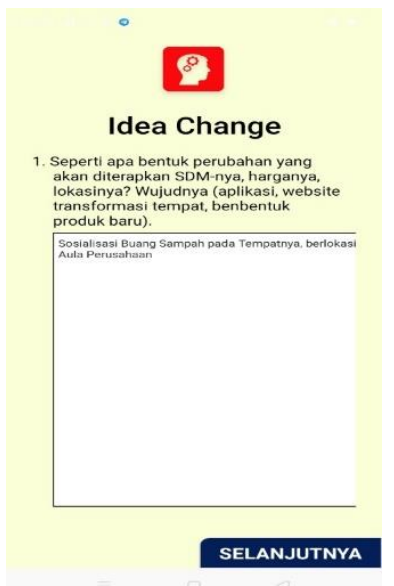

Figure 9. Idea Change Worksheet Menu 1

\section{8}

Idea Change

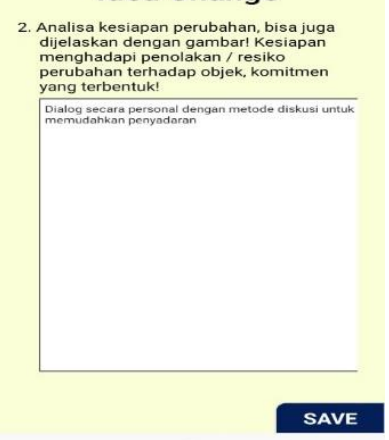

Figure 10. Idea Change menu worksheet 2 
On the Idea Design menu contains a worksheet on how steps are taken to make changes happen, after the contents are then click NEXT.

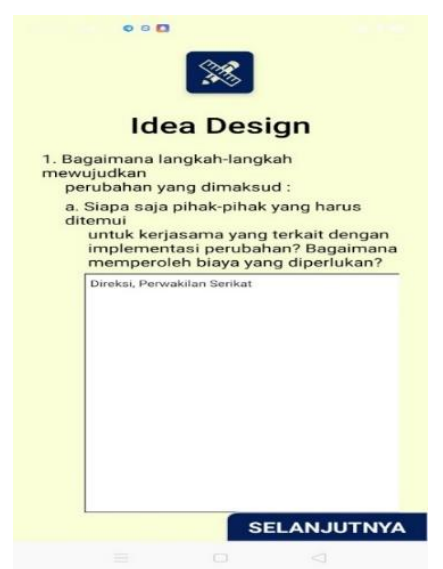

Figure 11. Idea Design menu worksheet 1

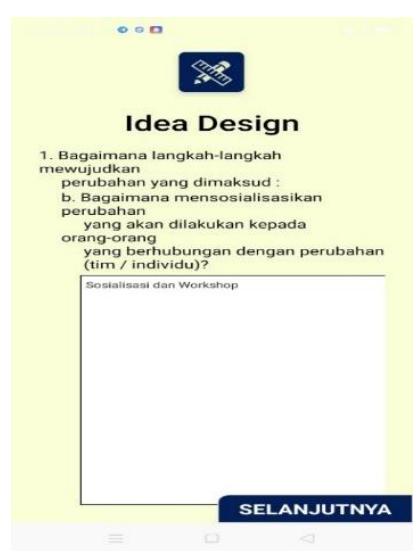

Figure 12. Advance Menu Design Idea Worksheet 1

After the Idea Design worksheet is filled in, until the design stage changes as shown below, it can be saved, so that the results can be saved. Theory Change menu contains Power Point change management material, CHAPTER 1 to CHAPTER 6, which can be downloaded, such as the following image. 


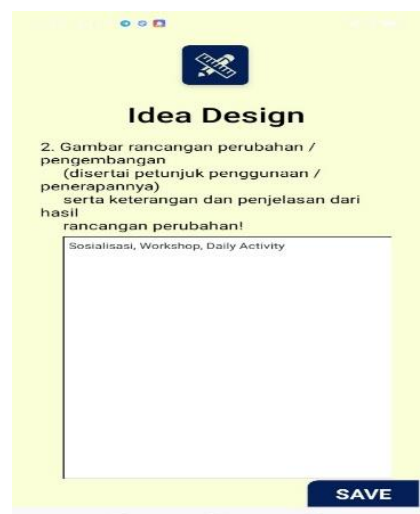

Figure 13. Idea Design Worksheet 2 Menu

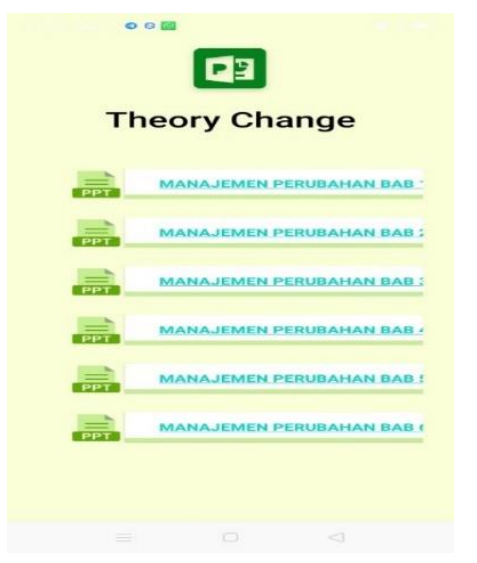

Figure 14. Menu Theory Change

The last menu is Idea success displaying a worksheet, which contains a successful evaluation of or not an implemented change which can be shown also with an image.

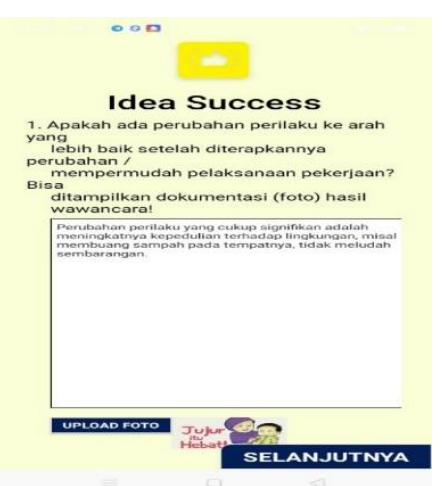

Gambar 15. Menu Idea Success

b. Application Implementation in Change Management class

This application is applied to students of Change Management class off Q, off QQ and Off P Class of 2018, where each individual is asked to look at the problems in their surroundings, then 
look for ideas for changes, and insert into the application as their worksheet then save (SAVE) on the menu provided.

Here's an example of one of the students' work off Q that fills the idea change menu:

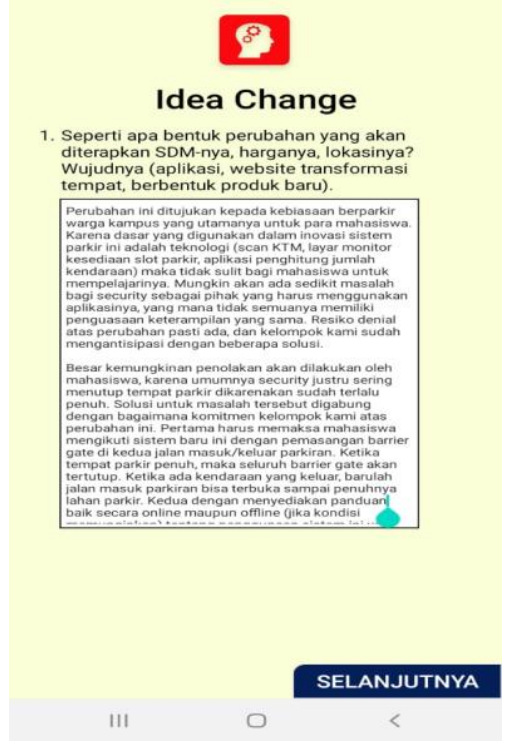

Figure 16. Idea Change Menu In student content

After students fill in the data on the application, then the data will be stored and recorded there is a summary so that it can be known the work of students, as in the excel table below is a recording of the results of register students who have registered and filled the problem portrait menu.

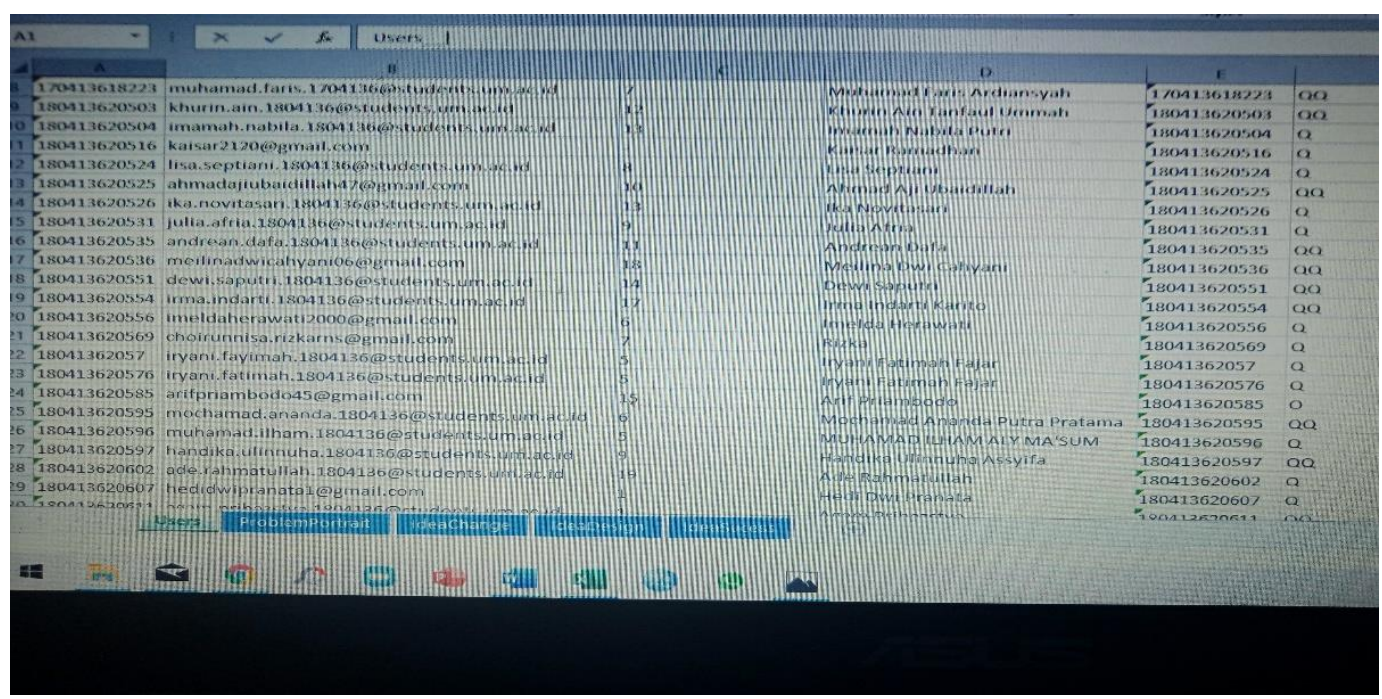

Figure 17. Student Registration Summary Data on Application

The results of student assessment of idea bank application, based on the questionnaire in the content, for the content aspect and display aspect $92 \%$ declared feasible, for the programming aspect $60 \%$ declared feasible, especially regarding the ease of use of media, many argued When first 
installing had experienced the application could not be installed on their android. The results of the assessment by media experts from aspects of media efficiency, button function and physical quality declared the application worthy of use.

\section{Discussion}

Idea Bank application product development consisting of problem portrait menu, idea change, idea design, theory change, and success idea has been validated by media experts and has been applied in change management class as electronic media, which is very appropriate for distance learning (Online), students of change management class asked the development team who built change management courses to install on their respective Android, in this case there are 2 students who asked, whether this application can be opened on a laptop or computer, because their HP IOS is not android, the development team explained that this application is designed based on android with the aim When students, looking for ideas to the field, the idea they find can be directly filled into android, without the hassle of bringing laptops, or write back to the computer when you get home, while based on android, because it is considered the average student uses hp based on android.

At the time of starting to install also many are experiencing problems, because there are settings that must be opened and not done by students, so many people ask, why can not install, given a solution to uninstall and then install again, and can be used. Due to time constraints so that this application is still many shortcomings in the programming aspect Hopefully this application is able to increase students' interest in learning change management courses, where so far the tendency is material and analysis that tends to be theoretical and has not reached the stage of practice or implementation of actual change management. As Kolb (1984) and Wallace (1994, in Millrood, 2001)said that adult learning would be more effective if learners were more directly involved than just passively accepting from teachers, based on Kolb's opinion it can be concluded that the application of this bank idea will be very useful as a place to pour ideas of student change in practice, so that they will have real experience in manage change both in the organization and society.

\section{Conclusion}

Based on the results of the development achieved, in the research of learning innovation development can be concluded: 1) Development of media application E-Learning Idea Bank consists of problem portrait menu, Idea Change, Idea Design, Idea Theory and Idea Success and Summary Data, 2) Application applied to change management class in Online lecture, as electronic learning media, 3) Constraints in the application is because based on android, there are some students based on IOS can not install.. 


\section{Acknowledgment}

Special thanks is expressed to Kemenristek/BRIN for providing grant funds in 2020 and for LPPM-PM Samudra University, who has contributed to this research in the field of administration.

\section{References}

[1] Arsyad, Azhar. 2007. Media Pembelajaran (Learning Media). Jakarta: Raja Grafindo Persada.

[2] Arsyad, Azhar. 2011. Media Pembelajaran (Learning Media). Jakarta: Rajawali Pers.

[3] Asyhar, Rayanda 2012. Kreatif Mengembangkan Media Pembelajaran (Creatively Developing Learning Media). Jakarta: Gaung Persada (GP) Press Jakarta.

[4] Borg, W. R., \& Gall, J. P. (1996). Educational research introduction (6th ed.). White Plains, NY: Longman Publishers USA.

[5] Millrood, R. (2001). Communicative language teaching.Modular course in EFL methodology. Tambov: Tambov state university.

[6] Sudjana, Nana dan Ahmad Rivai. (2002). Media Pengajaran (Learning Media). Bandung: Sinar Baru Algesindo. 